\title{
Siddha Concepts in Diagnosis and Management of COVID-19
}

Dr. M. Selvakumar M.D ${ }^{1 *}$, Dr. M. Suganthi M.D ${ }^{1}$, Dr. A. Aishwarya M.D ${ }^{1}$, Dr. T. Lakshmi Kantham M.D Ph.D ${ }^{2}$, Prof. Dr. R. Meenakumari M.D

${ }^{1}$ Siddha Physician, P. G. Alumnus, Department of Maruthuvam, National Institute of Siddha, Chennai-600047, Tamil Nadu, India

${ }^{2}$ Associate Professor, Department of Maruthuvam, National Institute of Siddha, Chennai, India

${ }^{3}$ Director, National Institute of Siddha, Chennai, India

Severe Acute Respiratory Syndrome Corona virus 2 (SARS-CoV-2) is also known as nCoV-2019. The causative pathogen of Corona virus disease 2019 (COVID-19) has been rapidly spreading across India and all over the world. No specific anti-viral drugs or vaccines are available for the treatment of this sudden and lethal disease. The supportive care and non-specific treatment to ameliorate the symptoms of the patients are the only options currently available. In our nation, we have good resources to treat nCoV-2019 affected patients with AYUSH (our own traditional medicines) especially Siddha medicines.Siddha system of medicine has unique methods to treat newly detected diseases. Siddhars deal with the human body as a spiritual entity rather than a material entity as dealt with by the western physiology. This study is to highlight the stage-wise diagnosis and treatment protocol as per Siddha literature in correlation to modern diagnosis and treatment of COVID - 19 patients.

Keywords: COVID-19, Siddha medicine, AYUSH.

Copyright @ 2020: This is an open-access article distributed under the terms of the Creative Commons Attribution license which permits unrestricted use, distribution, and reproduction in any medium for non-commercial use (NonCommercial, or CC-BY-NC) provided the original author and source are credited.

\section{INTRODUCTION}

Severe Acute Respiratory Syndrome Corona virus 2 (SARS-CoV-2) is also known as nCoV-2019. The causative pathogen of Corona virus disease 2019 (COVID-19) has been rapidly spreading across India and all over the world, causing an outbreak of acute infectious Pneumonia. No specific anti-viral drugs or vaccines are available for the treatment of this sudden and lethal disease. The supportive care and non-specific treatment to ameliorate the symptoms of the patients are the only options currently available. Despite the conventional therapies working at the topmost level, more than $85 \%$ of SARS-CoV2 infected patients in china are receiving Traditional Chinese Medicine combined with Allopathic treatment [1].

In our nation, we have good resources to treat nCoV-2019 affected patients with AYUSH (our own traditional medicines) especially Siddha medicines.

\section{Siddha system of medicine}

Siddha system of medicine has unique methods to treat newly detected diseases. Siddhars deal with the human body as a spiritual entity rather than a material entity as dealt with by the western physiology. Thus, the principles of diagnosis in Siddha differs from the western pathology [2].
Siddha always embraces a holistic approach in elaborating the details of a disease at hand. We have five-pronged approach in the elaboration of an unknown disease [3].

Adippadai (Noi Karanam) - Aetiology Munnam (Murkkurigal) - Symptoms Vadivam(Mukkuttra Thelivu) - Diagnosis Adaivu (Vazhimurai) - Line of treatment Punarppu (Noi Parikaram) - Treatment

\section{Adippadai (Noikaranam) - Aetiology}

Considering the Adippadai (Noikaranam), COVID-19 virus has evolved itself into a pandemic affecting a large population, irrespective of their physical features, dietary patterns, psychological attributes, etc...

\section{Munnam (Murkurigal) - Signs and Symptoms}

Referring to the details available from the places where COVID - 19 has affected, especially from China, about $40 \%$ of the cases were having very mild symptoms such as dry cough, sore throat, mild fever, head ache, running nose, nasal congestion and malaise - with no symptoms of dyspnoea and viral pneumonia. Another $40 \%$ of the cases were having moderate 
symptoms -- severe cough, shortness of breath, fever with mild pneumonia. $15 \%$ of the cases were having very severe symptoms -- dyspnoea, respiratory distress and hypoxia. However, the fever must be interpreted carefully because, even in severe forms of the disease, it can be moderate or even absent. $5 \%$ of the cases were found to be critical in presentation [4].

\section{Course of Signs and Symptoms}

In one report the main clinical features [5] shown were dry cough), running nose, nasal congestion and mild fever and this condition is interpreted in Siddha as Kasam (Erumal) and Peenisam. With symptoms of shortness of breath and fatigue developing later on, the condition is interpreted in Siddha as Eraippu- Uyirppu). With the condition further worsening with laboured breathing and persistent pain with fever it is interpreted as Kaba suram (Iya suram). Finally with the disease progressing to reach the terminal stage marked by tremor, severe dyspnoea and organ failure leading to death, the condition is interpreted in Siddha as Seethanga Janni.

Considering all these factors, COVID - 19 is a lethal syndrome, which is considered as a combination of many diseases. In the beginning, signs and symptoms start as Kasam (Erumal) and Peenisam. Then it aggravates as Kaba Iraippu (Iya Iraippu). If we fail to contain the symptoms within this stage it reaches a dangerous stage Kaba suram (Iya suram). Kaba suram leads to Seethanga Janni which one is rampant and lethal.

The course of symptoms helps us to find a way to provide proper treatment through Siddha System of Medicine. We can approach this situation by clinical staging method. The purpose of clinical staging is helpful to treat the signs and symptoms within the stage and break the chain reaction which leads to further critical level. There are four clinical stages.

\begin{tabular}{|c|c|c|}
\hline \multicolumn{2}{|r|}{ Stage -0} & $\begin{array}{l}\text { Patients with no symptoms or a positive travel history / contact } \\
\text { history/ home quarantine / isolation }\end{array}$ \\
\hline Stage -1 & Mild illness & $\begin{array}{c}\begin{array}{c}\text { Kasam (Erumal ) } \\
\text { [Dry cough, Sore throat, Loss } \\
\text { of taste, Tiredness] [6] }\end{array} \\
\begin{array}{c}\text { Peenisam } \\
\text { [Running nose, Nasal } \\
\text { congestion, Mild fever] [6] }\end{array} \\
\end{array}$ \\
\hline Stage -2 & Pneumonia & $\begin{array}{l}\text { Kaba eraippu (Iya eraippu) } \\
{[\text { Severe cough, Shortness of breath, Fever, Frequent wheezing, }} \\
\text { Chest pain, Fatigue, Thirst, Malaise, Loss of sleep, } \\
\text { Constipation and Low urine output] }[6,36]\end{array}$ \\
\hline Stage -3 & Severe Pneumonia & $\begin{array}{l}\text { Kaba suram (iya suram) } \\
\text { [Cough with expectoration, severe dyspnea, Chest pain, Fever, } \\
\text { Fatigue, Sweating] [16] }\end{array}$ \\
\hline Stage -4 & $\begin{array}{l}\text { Acute Respiratory Distress } \\
\text { Syndrome (ARDS), Sepsis, } \\
\text { Septic Shock }\end{array}$ & $\begin{array}{l}\text { Seethanga Janni (Kuliram) } \\
{[\text { Chillness of body, Tremor, Hiccup, Fatigue, Swoon, }} \\
\text { Vomiting, Diarrhoea, Severe thirst, Cough, Hypoxia, Organ } \\
\text { failure] }[6,16,36]\end{array}$ \\
\hline
\end{tabular}

\section{Vadivam (Mukkuttra Thelivu)- Diagnosis (Stage wise explanation) \\ Stage 1}

Uyirkkaal (Prana vayu) alters its nature and combines with Unthi kaal (Uthana vayu), Anal (body core temperature) and Iyam (Kabam). Then it would manifest as Kasam (Erumal). When this combination of mukkutram mingles with Kuruthi (Blood) -one of the seven Udal Thathukkal (Physical constituents) Peenisam will appear[3].

\section{Stage 2}

Vali (Vatham), raised with Iyam (Kabam), enters into the pathway of food and air. Due to the blockage, Iyam increases more and more within the chest and produces breathlessness. It leads to Iya eraippu (Kaba eraippu) ${ }^{(3)}$.

\section{Stage 3}

Vali (Vatham), Azhal (Pitham) and Iyam (Kabam) become rampant and mingle with seven thathukkal (Karukkal - constituent parts of the body) to produce Kaba suram (Iya suram)[3].

\section{Stage 4}

The Analam (Pitham) increases more and more and then divides to settle in abdomen and skin. It disbands abnormal temperature all over the body. So Vali (Vatham) and Iyam (Kabam) become detached and Agattanal (Sadarakkini) goes lame. Gradually this condition leads to organ failure and death [3].

As per the Siddha literature, if there are no signs of improvement in Seethanga janni within 14 days of proper treatment, the condition will become critical [3].

\section{A.Adaivu (Vazhimurai)- Line of treatment \& B.Punarppu (Noi Parikaram)- Treatment}

(Stage wise management protocol)

Stage 0:

- Patients with no symptoms or a positive travel history / contact history/ home quarantine / isolation 
- No symptoms or mild symptoms

- Consider this stage as a potential one which may lead to the onset of Kasam (Erumal) and Peenisam.

- Consider the patient's age and other co- morbidities.

- Advise the patient to follow the community prevention protocols.

- The following procedures, taken from the Siddha literature (indicated side by side), are simple effective remedies and are easy to follow with confidence.

Gargling - water boiled with salt (Kalluppu - Table salt/Sea-salt)/ Thiribala choornam/ Manjal (Turmeric)/ Padigara neer.

Drinking water: (any one of the following medicine can be prescribed)

- Water boiled with Seeragam (Cuminum cyminum. Linn). It reduces the influence of Kabam) [6].

- Use Puthina keerai (Mentha arvensis .Linn.) as tea or chutney[7]

- $\quad$ Thuththi leaf (Abutilon indicum .Linn.) tea[8]

- Turmeric (Curcuma longa. Linn.) tea with vellam (jaggery) [8]

\section{Steam inhalation}

- Use Notchi leaf (Vitex negundo .Linn.) with turmeric for steam inhalation [8].

\section{Food}

- Favourable: Easily digestible light food in semi-solid state like kanji (Porridge) with onion, curry leaf, garlic, lime, zinger, turmeric, cumin seeds, chukku (dried ginger), cooked vegetables. Use warm water for drinking. Take complete rest.

○ Unfavourable: Heavy, oily, spicy, fried foods; junk foods, curd, cool drinks, mental stress.

Internal medicines to boost our immune system: (any one of the following medicine can be prescribed)

- Agnimuga choornam (dose; $1 / 2$ thola - 4 to $5 \mathrm{gm}$ with lukewarm water, bid)[9]

- Seeraga choornam (dose; 1 to 2 gm with lukewarm water, bid)[10]

- Dratchathi choornam (dose; 1 to 2 gm with honey, bid)[11]

- Nilaavarai choornam (dose; 1 to $2 \mathrm{gm}$ with lukewarm water, bid)[12]

- Thiribala choornam (dose; 1 to $2 \mathrm{gm}$ with lukewarm water, bid)[13]

- Inji ilagam (dose; 6 to 12 gm, bid)[14]

- Thetran kottai ilagam (dose; 3 to 6 gm, bid)15]

The above medicines help to remove aamam in our stomach and abdomen which affects Agattanal (Sadarakkini). Aamam weakens our immune system and makes our body easily susceptible to infection [3].

\section{Stage 1: Kasam (Erumal, Peenisam)}

(i) Noi nadai

There is inflammation of mucus layer (silethumna savvu) of bronchus. There are two types of onset. One comes with fever and it is virulent. The other one comes without fever and it is chronic in nature. When it affects the children, it is called ALLU MANTHAM. Mucus comes out easily when it affects larger Bronchi. If mucus accumulates within the smaller bronchioles and alveoli, it does not come out easily. It prevents the air flow and decreases blood purification in the lungs. It leads to dangerous respiratory distress. So the vaithiyar (doctor) who treats the patients with inflammations in smaller bronchioles and alveoli must be very careful. With our Siddha treatment, mucus comes out largely and it should not be prevented. Respiratory distress will occur when mucus stays within the lungs. The lethal symptoms are swelling of both the legs and prattling.

At first we treat with Balagari (tonic) medicines. In Kasarogam (cough), it is a rule to give the medicine every 3 to 4 hours [16].

\section{(ii) Simple remedy}

a. Poultice: (any one of the following medicine can be prescribed)

i. Add Chukku powder (dried Zingiber officinale .Linn.) to Rice powder and make it into kali (semi solid state) and use it as poultice on fore head for head ache and apply on throat externally for throat pain [17].

ii. Add Karunjeeragam powder (Nigella sativa .Linn.) to water and use it as poultice on forehead for head ache [18].

iii. Add hydrated lime (Karchunnam $-\mathrm{CaCO}_{3}$ ) (200 $\mathrm{mg}$ ) to jaggery and use it as poultice on throat externally [8].

iv. Add Kadugu (Brassica juncea .Linn) to water and use it as poultice on the chest and it will help to bring relief from Kasam (Erumal) [13].

\section{b. Nasal fumigation}

i. Mix together equal quantities of powder form of the herbs namely Thippili (Piper longum .Linn.), Manjal (Curcuma longa .Linn.), Omum (Carum copticum Linn.) and Milagu (Piper nigram Linn)[19]. By treating with the mixed powder, make wicks with small pieces of cotton cloth. Use this medicated wick for nasal fumigation with veppennai (neem oil).

c. Nasikaparanam (Snuff)

i.(i) Finely powdered Chundai ver (Root of Solanum torvum Linn.) can be used as snuff [20].

d. Nasal drops, Ear drops

i.(i) Use Chukku thylam as nasal and ear drops [21] 


\section{e. Steam inhalation}

(i) Water or Milk for Kasam (Erumal)

(ii) Take Seeragam (Cuminum cyminum .Linn.) powder 2 to $4 \mathrm{gm}$ along with Karkandu (sugar candy) forErumal (Cough) [22]

(iii) Take Karunjeeragam (Nigella sativa .Linn.) 1 to $2 \mathrm{gm}$ along with Notchi (Vitex negundo .Linn.) kudineer for Peenisam (Sinusitis), Head ache, Fever and Wheezing [18].

(iii) Medicines for Kasam with Suram (Cough with Fever): (any one of the following medicine can be prescribed)

a. Adathodai leaf kasayam (decoction) [16]

b. Thumbai leaf juice or kasayam [22]

(iv) Medicines for Kasam (Cough) without Suram (Fever) : (any one of the following medicine can be prescribed)

a. Musumusukkai leaf surasam [surasam - a medicinal juice warmed by introducing a red hot iron] [18]

b. Kandangathari kasayam with Vaal milagu powder[18]

c. Sadamaanjil kasayam with Athimathuram powder[18]

d. Goat milk[25,7] or raw Cow milk

e. Valenthira polam powder (10 to 15 ulunthu nirai) 650 $\mathrm{mg}$ to $975 \mathrm{mg}$ with milk[18]

f. Araththai powder with Vellulli (poondu) [16]

g. Elathi choornam(5 to 10 kundri edai - 600 to $1200 \mathrm{mg}$ or nei with Navacharam (Ammoni chloridum) [17]

h. Thuthulai nei (4 to $8 \mathrm{ml}$, bid[12] or Rasayanam

i. Perungaya ilagam (dose; $5 \mathrm{gm}$, bid) [9]

j. Thippili ilagam or Rasayanam (3 - 6 gm, bid)[15]

k. Vishnu kiranthi powder with Vattathiruppi powder [18]

(v) Medicines for Dry Cough (Kasam): (any one of the following medicine can be prescribed )

a. Athimathuram kasayam with honey[17]

b. Arathai kasayam 30 to $40 \mathrm{ml}$ with honey[17]

c. Vendaikkai kasayam 30 to $70 \mathrm{ml}$ with honey[13]

d. Nerunjil kasayam with honey [18]

e. Thulasi vithai kasayam with honey $[22,20]$

f. Agasathamarai surasam $40 \mathrm{ml}$ with honey [surasam a medicinal juice warmed by introducing a red hot iron] [18]

g. Karuvelam pisin (3 to $5 \mathrm{gm}$ ) [18]

h. Kasakasa ilagam (4 to $8 \mathrm{gm})$ [13]

i. Boiled milk with milagu (Black pepper)

j. Take $1 / 2$ part of Jathikkai and 1 part each of Athimathuram, Vaal milagu, Arathai, Lavangam. Prepare fine powder of these ingredients and mix well. Dose: $1 / 2$ to 1 varagan edai ( 2 to $4 \mathrm{gm}$ ) / three or four times a day with honey. This is a special preparation for dry cough. (vi) Medicines for Kasam in children (ALLU MANTHAM ): (any one of the following medicine can be prescribed )

a. Gorosanai mathirai[12] (or) Arathai powder[18] (or) Athimathuram powder[18] along with $1 / 2$ uchikarandi (8ml) of any of the following adjuvant:

i. Vettrilai surasam [surasam - a medicinal juice warmed by introducing a red hot iron ] (or)

ii. Thulasi surasam (or)

iii. Karpooravalli surasam (or)

iv. Thiruneetru pachai surasam

\section{Stage 2: (Iya Eraippu)}

(i) Noi nadai

Difficulty in breathing, Loss of sleep, Cough with expectoration, respiratory distress [3]

(ii) Fumigation :(any one of the following medicine can be prescribed)

a. Oomathai ilai suruttu[13]

b. Pottiluppu (Pottassi Nitras)[23]

(iii) Purgation : (any one of the following medicine can be prescribed)

a. Sanjeevi mathirai (dose ; 1 or 2 , od, with uthamani juice)[24]

b. Uthamani ennai (8 to $15 \mathrm{ml}$, od)[21]

c. Lavangathi mathirai (dose ; 1 to 4 with lukewarm water, od)[14]

d. Thalamboo mathirai (dose ; 1 to 2 with honey or lukewarm water, od)[14]

(iv) Medicines for Eraippu (any one of the following medicine can be prescribed )

a. Adathodai leaf kasayam with uthamani [16]

b. Vasambu kasayam (dose; 15 to $30 \mathrm{ml})[17,13]$

c. Sadamanchil kasayam [18]

d. Goat milk $[25,7]$

e. Valenthira polam (10 to 15 ulunthu nirai) $650 \mathrm{mg}$ to $975 \mathrm{mg}$ with milk [18]

f. Bavanai Omam (dose ; 1 to 2 gm , bid) [18]

g. Bavanai seeragam (dose ; 4 to 8 gm, bid) [22]

h. Karpoorathi choornam (dose ; $650 \mathrm{mg}$ to $1300 \mathrm{mg}$ ) [23]

i. Perungaya choornam (1 to 2 gm, bid) [17]

j. Kandangathari kudi neer (dose ; 30 to $60 \mathrm{ml}$, bid) [17]

k. Thippili ilagam or Rasayanam (3 - 6 gm, bid) [15]

1. Suvaasa Kasa Mathirai (dose ; $65 \mathrm{mg}, 3$ to 4 hours once) [9]

m. Thuthulai kirutham (4 to $8 \mathrm{ml}$, bid) [12]

n. Kanthaga mathirai (dose ; 1 or 2 , od )[14]

o. Aya chenthuram (dose ; 100 to $200 \mathrm{mg}$ with honey, bid)[15]

p. Thambira parpam (dose ; 50 to $100 \mathrm{mg}$ with honey, bid) [15] 


\section{Stage 3: (Kaba suram - Iya suram)}

\section{(i) Noi nadai}

If Stage 2 is not addressed properly, the thega vanmai (Immunity) of the patient weakens and as a result the body temperature rises (Atthi ushnam). When the majjai thathu, one of the seven Udal Thathukkal (Seven physical constituents) is affected, head ache, extreme tiredness, chill and fatigue are produced. The Raktha thathu (Blood) is also affected with accumulation of waste by-products. If we fail to clear this mess through therapeutic purgation and therapeutic emesis, a number of serious diseases will be produced.

External origin of some poisonous thing goes inside the body and raise the temperature. It is called fever. After this Aththi ushnam is raised tremendously. It declines the seven thathu and physiology. Due to this some waste byproducts mixed with blood. If we fail to clear this mess through purgation and vomiting procedures it will cause innovative diseases to our body. When machai thathu (one of seven thathu) is affected it produce head ache, extreme tiredness, chill and fatigue [16]

Purgation: (any one of the following medicine can be prescribed)

a. Agasthiyar kulambu - 100 to $200 \mathrm{mg}$ with chukku karkam [26] or

b. Kowsigar kulambu - 100 to $200 \mathrm{mg}$ with elakkai powder or hot water [14] or

c. Meganatha kuligai [27] or

d. Lavangathi mathirai [14]

(ii) Kasayam (every two to three hours):(any one of the following medicine can be prescribed)

a. Kaba sura kudineer (dose ; 30 to $60 \mathrm{ml}$ ) [14]

b. Nila vembu kudineer (dose ; 30 to $60 \mathrm{ml}$ ) [14]

c. Nanjusura kudi neer (dose ; 30 to $60 \mathrm{ml}$ ) [16]

d. Veppam pattai kasayam (dose ; 30 to $45 \mathrm{ml}$ )[18]

e. Kostam kasayam (dose ; 15 to $20 \mathrm{ml}$ with honey, bid) [13]

f. Seenthil kasayam (dose ; 40 to $50 \mathrm{ml}$ with powder of lavangapattai or lavanm, bid) [13]

(iii) Choornam : (any one of the following medicine can be prescribed )

a. Maha sutharsana choornam (dose $3 \mathrm{gm}$ with lukewarm water, bid) [9]

b. Karpoorathi choornam (dose ; $650 \mathrm{mg}$ to $1300 \mathrm{mg}$ ) [23]

c. Atathodai choornam (dose ; 1000 to $1500 \mathrm{mg}$, bid with milk) [9]

(iv) Mathirai :(any one of the following medicine can be prescribed )

a. Anantha bairavam (dose ; 1 to 2 with honey or inji juice, bid) [8]

b. Pachai karpoora mathirai (dose ; 1 to 2 with honey or inji juice, od) [14] c. Thirithoda mathirai (dose ; 1 to 2 with milagu

kasayam, bid [14]

d. Asta bairava kuligai (dose ; 1 to 2 with honey or inji juice, od) [14]

(v) Parpam: (any one of the following medicine can be prescribed)

a. Pon parpam (dose ; 100 to $200 \mathrm{mg}$ with sugar) [28]

b. Thambira parpam (dose ; 50 to $100 \mathrm{mg}$ with sugar)

[15]

c. Ayanaga parpam (dose; 100 to $200 \mathrm{mg}$ with honey) [28]

d. Velleeya parpam (dose ; 100 to $200 \mathrm{mg}$ with thulasi juice) [15]

e. Thalaga parpam (dose ; 25 to $50 \mathrm{mg}$ with thiruneetru pachilai juice) [14]

(vi) Chenthuram : (any one of the following medicine can be prescribed )

a. Gowri chinthamani chenthuram (dose ; 100 to $200 \mathrm{mg}$ with Tirikadugu choornam and honey, bid) [29]

b. Velli chenthuram (dose ; 50 to $100 \mathrm{mg}$ with ghee,bid) c. Shaya kulanthaga chenthuram (dose ; 50 to $200 \mathrm{mg}$ with Tirikadugu choornam and honey, bid) [31]

\section{Stage 4: (Seethanga janni)}

(i) Noi nadai

Chillness of body, Tremor, Hiccup, Fatigue, Swoon, Vomiting, Diarrhea, Severe thirst, Cough, Hypoxia, Organ failure [32].

(ii) Kulambu (any one of the following medicine can be prescribed )

a. Agasthiyar kulambu - 100 to $200 \mathrm{mg}$ with chukka karkam [26]

b. Kowsigar kulambu - 100 to $200 \mathrm{mg}$ with elakkai powder or hot water [14]

(iii) Mathirai:(any one of the following medicine can be prescribed )

a. Anantha bairavam (dose ; 1 to 2 with honey or inji juice, bid)[8]

b. Rajarajeswaram (dose ; 1 with Thirikadugu Kasayam, bid)[14]

c. Sanni patha bairavam (dose ; $25 \mathrm{mg}$ with Palm jagary or milk) [33]

\section{(iv) Melugu}

a. Panja sootha melugu (dose ; 100 to $200 \mathrm{mg}$, bid) [34]

(v) Parpam:(any one of the following medicine can be prescribed)

a. Thambira parpam (dose ; 50 to $100 \mathrm{mg}$ with sugar)

[15]

b. Mutthu parpam (dose ; 50 to $100 \mathrm{mg}$ with milk or ghee, bid)[11]

c. Pavala parpam (dose ; 100 to $200 \mathrm{mg}$ with Thuthulai juice or milk, bid) [35]

d. Peranda parpam (dose ; 100 to $300 \mathrm{mg}$ with inji charu and sugar, bid) [10] 
(vi) Chenthuram: (any one of the following medicine can be prescribed)

a. Linga chenthuram (dose ; 50 to $100 \mathrm{mg}$ with Thirikadugu choornam and honey, bid) [15]

b. Sanda marutham (dose ; 50 to $100 \mathrm{mg}$ with Inji juice, Thirikadugu choornam, Amukkra choornam and honey, bid) [14]

\section{CONCLUSION}

- The purpose of this study is to highlight the stage-wise diagnosis and treatment protocol as per Siddha literature in correlation to modern diagnosis and treatment of COVID - 19 patients.

- In this paper, simple remedies from reliable sources and easy to follow safe guidelines have been given.

- Most of the Siddha medicines are taken from classical (sastric) Siddha books and they are easily available in stores. In case of any emergency situation, we can use these medicines immediately.

- Most of these medicines are cost-effective.

- Considering all these factors, we can make an integrative approach in providing standard Siddha treatment combining with modern medication for COVID-19 patients.

\section{REFERENCES}

1. COVID-19: An update on the epidemiological, Clinical, Preventive and Therapeutic Evidence and Guidelines of Integrative Chinese - Western Medicine for the management of 2019 Novel Corona virus Disease. Kam Wa Chan, Vivian Thaan Wong, Sydney Chi Wei Tang/ et.al.Am J Chin. Med. 2020;https://pinned.ncbi.nlm.nih.gov/32164424/

2. Principles of diagnosis in Siddha, Part 1,Dr.M.Shanmugavelu H.P.I.M., Dr. K. Natarajan B.I.M., Dr.Anaivari R.Ananthan Ph.D., 2009.

3. Manmurugiyam ennum Tamil Maruthuva Nool, Part 2 (Noi Araichi Padalam ), Kavirasa Panditha Rama subrsmaniya Navalar, 1969.

4. https:/www.who.int $>$ docsPDF Report of the WHO-China Joint Mission on Coronavirus Disease 2019 (COVID-19)

5. https://www.cdc.gov/coronavirus/2019ncov/symptoms-testing/symptoms.html

6. Agathiyar vaithiya sathagam, Agathiyar, First edition, April 2000.

7. Pathartha guna sinthamani, Dr.Anaivari Ananthan Ph.D., First edition, 2007.

8. Vaithiya perungural, Dr.K.S.Dheventhiranatha Pandithar, First edition, 1964.
9. Sigitcha rathna dheepam, Vaithiya Vithvan Mani C. Kannusami pillai, First edition, 2007.

10. Pulippani vaithiyam 500, First edition, December 1999.

11. Therayar karisal 300, Theraiyar,First edition, 1915.

12. Agathiyar vaithiya rathina churukkam, Agathiyar, First edition, 2009.

13. Gunapadam Porutpanbu Nool -Mooligai, Vaithiyam Rathinam Dr.K.S.Murugesa Muthaliyaar, Second edition, 2008.

14. Siddha vaithiya thirattu, Dt.K.N.Kuppusamy Muthaliyaar, Dr.K.S.Uthamarayan H.P.I.M., First edition, 1995.

15. Agasthiyar paripooranam 400, Agathiyar,First edition, 1995.

16. Therayar Vagadam, Therayar, First edition, 2000.

17. Therayar Gunavagadam, Therayar, Second edition, 2014.

18. Agathiyar gunavagadam, Agathiyar, First edition, 1973.

19. Theran segarappa, Therayar,First edition , 2000.

20. Theran kaapiyam, Therayar, First edition, 1975.

21. Therayar thila vargam, Therayar

22. Therayar venba, Therayar, First edition, 1974.

23. Gunapadam -Thathu \& Jeevam, Dr. R. Thiyagarajan L.I.M., Second edition, 2009.

24. Agasthiyar vaithiyam 600, Agathiyar, First edition, 1924.

25. Theran tharu, Therayar, Dr. R. Thiyagarajan L.I.M., First edition, 1997.

26. Agasthiyar amutha kalaignanam - 1200, Agathiyar, First edition, 1928.

27. Agasthiyar sillarai kovai, Agathiyar.

28. Siddha maruthuvam pothu, Dr.K.N.Kuppusamy Muthaliyaar H.P.I.M., Seventh edition, 2007.

29. Agasthiyar vaithiya kaviyam 1500, Agathiyar, First edition, 1994.

30. Therayar yamagam, Therayar, Second edition; 2003.

31. Agasthiyar pin 80, Agathiyar.

32. Periya vaithiya arichuvadi, Sri T. Kuppusamy Naidu, First edition, 1930.

33. Vaithiya sinthamani \& Kannusamiyam, Vaithiya Rathinam Dr. C.Kannusamy Pillai, First edition, 2007.

34. Yugi karisal 151, Yugi munivar, First edition; 1915.

35. Thanvanthiri vaithiya kaviyam 1000, Thanvanthiri, First edition, 1931.

36. Yugi Munivar Vaithiyam Sinthamani -800, Yugi Munivar, First edition, 1976. 